www.jmscr.igmpublication.org

Impact Factor 5.84

Index Copernicus Value: 71.58

ISSN (e)-2347-176x ISSN (p) 2455-0450

crossref DOI: _https://dx.doi.org/10.18535/jmscr/v5i9.138

Journal Of Medical Science And Clinical Research

\title{
A Clinico-Pathological Analysis of Causes of Abnormal Uterine Bleeding According to PALM -COEIN Classification: Study based in a Rural Teaching Hospital of Central India
}

\author{
Authors \\ Rekha Ratnani $^{1}$, Naik Meena ${ }^{2}$ \\ ${ }^{1}$ Prof and HOD, Dept of Obgyn, CCM Medical College, Durg, CG \\ ${ }^{2}$ Asst Prof, Dept of Obgyn, CCM Medical College, Durg, CG \\ Corresponding Author \\ Naik Meena \\ Asst Prof, Dept of Obgyn, CCM Medical College, Durg, CG
}

\begin{abstract}
Aim
To study various causes of AUB and classify them according to new FIGO system of PALM COEIN classification.
\end{abstract}

\section{Introduction}

Abnormal Uterine Bleeding (AUB) is a significant debilitating clinical condition and affects $14-25 \%$ of women of reproductive age and up to $50 \%$ of perimenopausal women. ${ }^{(1-3)}$

Abnormal uterine bleeding (AUB) may be acute or chronic and is defined as bleeding from the uterine corpus that is abnormal in regularity, volume, frequency, or duration and occurs in the absence of pregnancy ${ }^{[4,5]}$.

Acute AUB is defined as bleeding in a nonpregnant woman of reproductive age of sufficient quantity to require immediate intervention to prevent further loss ${ }^{(6,7)}$ Chronic AUB is defined as bleeding from the uterine corpus that is abnormal in duration, volume, and/or frequency and has been present for most of the previous 6 months. ${ }^{(6)}$
Historical literature of AUB reveals no universally accepted method for classifying AUB, which hampered the investigation and categorization of possible etiologies of AUB. ${ }^{(8)}$ The classic terminology that describes AUB include terms that are not related to the underlying etiology (e.g., menorrhagia, polymenorrhea etc.).

In order to standardize definitions, nomenclature and the possible underlying etiologies of AUB, and in an effort to create a universally accepted system of nomenclature to describe uterine bleeding abnormalities in reproductive-aged women, an alternative classification system polyp, adenomyosis, leiomyoma, malignancy and hyperplasia, coagulopathy, ovulatory dysfunction, endometrial, iatrogenic, and not yet classified, known by the acronym PALM-COEIN, was redefined by International Federation of Obstetrics and Gynecology (FIGO) in 2009 and published in 2011 by the International Federation of Gynecology and Obstetrics and adopted by the 
American College of Obstetricians and Gynecologists $^{(9)}$.

The PALM-COEIN system classifies uterine bleeding abnormalities by bleeding pattern and etiology. The overarching term AUB is paired with descriptive terms to denote bleeding patterns associated with AUB, such as heavy menstrual bleeding (instead of menorrhagia) and intermenstrual bleeding (instead of metrorrhagia). The term dysfunctional uterine bleeding - often used synonymously with AUB in the literature to indicate AUB for which there was no systemic or locally definable structural cause - is not part of the PALM-COEIN system, and discontinuation of its use is recommended ${ }^{[9]}$.

By using this system, the possibility of contribution of more than one pathology in an individual symptomatic woman and also lack of contribution of a coincidental asymptomatic pathology toward AUB due to other causes can be recognized. ${ }^{(10)}$

\section{Materials and Methods}

This study was carried out at a rural tertiary teaching hospital of central india, in department of Obstetrics and gynaecology, CCM medical college, kachandur, Durg, Chhatisgarh.

300 women with complaints of abnormal uterine bleeding were included in the study

All women between 20-70 yrs who presented to gynae OPD between January 2015 to December 2015 with abnormal uterine bleeding were included in study excluding pregnant women and those with overt malignancy of lower genital tract. patients were thoroughly evaluated with detailed history, examination, necessary blood investigations and sonography. followed by either D \& C or hysteroscopy. histopathological exam of endometrium or hysterectomy specimen were reviewed and all women categorised according to the new FIGO -PAL M -COEIN classification system.

Patients with polyps on per speculum exam or sonography or hysteroscopy were categprised as AUB -P .those with either adenomyosis or leiomyoma on sonography or hysterectomy specimen were categorised as AUB-A or AUB -L .many patients had both these so they were counted in both categories .bleeding due to endometrial hyperplasia or endometrial carcinoma diagnosed on hysteroscopic biopsy or hysterectomy were included in AUB -M.

These were all organic or structural causes of AUB. Other non structural causes were categorised in COEIN. AUB $-\mathrm{C}$ for bleeding due to coagulation disorders .irregular bleeding due to ovulatory dysfuntion where no structural causes identified and where endometrial biopsy was either proliferative were included in AUB-O. Endometrial causes, AUB-E included cases with endometritis and iatrogenic bleeding, AUB- I. was due to irregular hormonal intake,

Some casues identified that did not fit into any of the above category like placental polyp, adhesions, etc were grouped in AUB-N.

Data for 300 women tabulated and analysed.

\section{Observations and Results}

Table 1-Age distribution of patients

\begin{tabular}{|l|c|c|}
\hline Age group & Total no & $\%$ \\
\hline$<20$ yrs & 0 & 0 \\
\hline $20-29$ yrs & 6 & $2 \%$ \\
\hline $30-39 y r s$ & 42 & $14 \%$ \\
\hline $40-49 y r s$ & 210 & $70 \%$ \\
\hline yrs & 34 & $11.3 \%$ \\
\hline$\geq 60$ yrs & 8 & $2.65 \%$ \\
\hline Total & 300 & \\
\hline
\end{tabular}

Majority ie $70 \%$ of patients in our study were in $40-50 \mathrm{yr}$ age group ,14\% in 30-40 yr age group, $11.3 \%$ in $50-60 \mathrm{yr}$ age group $.2 .65 \%$ and $2 \%$ were in $>60$ and $<30$ yr age group .none of patients were below 20 in our study population .

Table 2-distribution according to symptoms

\begin{tabular}{|l|c|c|}
\hline symptoms & Total no & $\%$ \\
\hline Heavy menstrual bleeding & 130 & $43.3 \%$ \\
\hline Irregular heavy bleeding & 60 & $20 \%$ \\
\hline Intermenstrual bleeding & 5 & $1.65 \%$ \\
\hline Frequent bleeding & 60 & $20 \%$ \\
\hline Postmenopausal bleeding & 42 & $14 \%$ \\
\hline Infrequent or scanty bleeding & 3 & $1 \%$ \\
\hline
\end{tabular}




\section{JMSCR Vol||05||Issue||09||Page 28196-28200||September}

Majority of patients complained of regular heavy bleeding as chief complaint (43.3\%)

$20 \%$ each had irregular heavy bleeding and frequent bleeding respectively.

$14 \%$ had postmenopausal bleeding, $1.65 \%$ had intermenstrual spotting and $1 \%$ had scanty bleeding.

Thus menorrhagia was the chief complaint in our study population followed by menometrorhagia and polymenorrhoea.

Table 3: Distribution of study population according to PALM - COEIN classification

\begin{tabular}{|l|c|c|}
\hline & $\begin{array}{c}\text { Total no of } \\
\text { patients }\end{array}$ & $\%(\mathrm{n}=300)$ \\
\hline $\begin{array}{l}\text { Polyp } \\
\text { (P) }\end{array}$ & 40 & $13.3 \%$ \\
\hline $\begin{array}{l}\text { Adenomyosis } \\
\text { (A) }\end{array}$ & 60 & $20 \%$ \\
\hline $\begin{array}{l}\text { Leiomyoma } \\
\text { (L) }\end{array}$ & 105 & $35 \%$ \\
\hline $\begin{array}{l}\text { Malignancy } \\
\text { (M) }\end{array}$ & 65 & $21.6 \%$ \\
\hline $\begin{array}{l}\text { Coagulopathy } \\
\text { (C) }\end{array}$ & 270 & $0.6 \%$ \\
\hline $\begin{array}{l}\text { Ovulatory } \\
\text { disfunction (O) }\end{array}$ & 3 & $20 \%$ \\
\hline $\begin{array}{l}\text { Endometrial } \\
\text { (E) }\end{array}$ & 80 & $1 \%$ \\
\hline $\begin{array}{l}\text { Iatrogenic } \\
\text { (I) }\end{array}$ & 3 & $1 \%$ \\
\hline $\begin{array}{l}\text { Not yet classified } \\
\text { (N) }\end{array}$ & 2 & \\
\hline & & \\
\hline
\end{tabular}

According to PALM -COEIN classification, structural causes accounted for majority of patients in our study, with 220 patients with structural causes .out of that about 50 patients had multiple causes like adenomyosis with fibroid or adenomyosis with hyperplasia.

Most common cause of AUB in our study was liomyoma in 105 (35\%) patients .endometrial hyperplasia and malignancy accounted for 65 $(21.6 \%)$ cases while $60(20 \%)$ patients had adenomyosis as cause of AUB. And 40(13.3\%) patients had polyps either endometrial or endocervical as cause of AUB.

About $80(26.6 \%)$ patients had non structural causes of AUB in our study. 60 (20\%) patients had ovulatory dysfunction, $12 \quad(4 \%)$ had endometrial cause in form of endometritis. 2 patients had coagulopathy, 3 had irregular hormone intake (iatrogenic) as the cause while in 3 cases the cause does not fit into any of the above category hence was included in Not yet classified category (placental polyp, adhesions)

Table 4: Distribution of causes of AUB in various age groups

\begin{tabular}{|l|c|c|c|c|c|}
\hline causes & $\begin{array}{c}20- \\
30 \mathrm{yrs}\end{array}$ & $\begin{array}{c}30- \\
40 \mathrm{yrs}\end{array}$ & $\begin{array}{c}40- \\
50 \mathrm{yrs}\end{array}$ & $\begin{array}{c}50- \\
60 \mathrm{yrs}\end{array}$ & $>60 \mathrm{yrs}$ \\
\hline $\begin{array}{l}\text { Polyp } \\
\text { (P) }\end{array}$ & 1 & 9 & 21 & 6 & 2 \\
\hline $\begin{array}{l}\text { Adenomyosis } \\
\text { (A) }\end{array}$ & 0 & 0 & 54 & 6 & 0 \\
\hline $\begin{array}{l}\text { Leiomyoma } \\
\text { (L) }\end{array}$ & 4 & 12 & 84 & 5 & 0 \\
\hline $\begin{array}{l}\text { Malignancy } \\
\text { (M) }\end{array}$ & 1 & 5 & 53 & 7 & 6 \\
\hline $\begin{array}{l}\text { Coagulopathy } \\
\text { (C) }\end{array}$ & 0 & 0 & 2 & 0 & 0 \\
\hline $\begin{array}{l}\text { Ovulatory } \\
\text { disfunction (O) }\end{array}$ & 0 & 2 & 7 & 3 & 0 \\
\hline $\begin{array}{l}\text { Endometrial } \\
\text { (E) }\end{array}$ & 0 & 0 & 3 & 0 & 0 \\
\hline $\begin{array}{l}\text { Iatrogenic } \\
\text { (I) }\end{array}$ & 0 & 3 & 0 & 0 & 0 \\
\hline $\begin{array}{l}\text { Not yet classified } \\
\text { (N) }\end{array}$ & 0 & 38 & 7 & 0 \\
\hline
\end{tabular}

When the causes of AUB were stratified according to age group, leiomyoma was the main cause in 20-30 yr age group while polyp and hyperplasia of endometrium as other causes.

In 30-40 yr age group ovulatory dysfunction was main cause followed by leiomyomas and polyp. hyperplastic endometrium was seen in some cases.

In 40-50 yr age group leiomyomas and adenomyosis were main causes while hyperplasia and malignancy also majorly contributed to the cause of AUB.

In $>60 \mathrm{yr}$ age group malignancy was the main cause and polyp in few cases.

\section{Discussion}

PALM -COEIN classification enables us to classify patients according to various structural and non structural causes it is universally 
accepted classification system with management startegies outlined according to specific causes .thus it enables proper management of the cause of AUB .similar study was undertaken by Khrouf et al.; ${ }^{[11]}$, Munro et al. $;^{[6]}$, Madhra et al.; (12), Bahamondes and Ali ${ }^{(13)}$

According to the study done by Qureshi and Yusuf $^{(14)}$ in 2013, maximum patients of AUB were classified under leiomyoma category, the number being $25 \%$ followed by ovulatory dysfunction $(24 \%)$.

Whereas, in a study done by Gouri et al.; (15) in May 2016, maximum number of patients were categorized under ovulatory dysfunction (27\%) followed by leiomyoma (24.67\%).

In our study leiomyoma was the main cause followed by hyperplasias and malignany, adenomyosis and ovulatory dysfunction.

Polyps were casue of AUB in $13.3 \%$ cases in our study .another study by Doraiswamy et al also showed that polyps accounted for $11.2 \%$ of cases of AUB.

In our study adenomyosis was found in $20 \%$ cases .other authors also reported adenomyosis as imp cause in study of Quereshi et al $15 \%$ cases of AUB had adenomyosis it was one of the common causes of AUB between 35-50 yr age group as found in our study also . According to Taran et al, 70 to $80 \%$ of women undergoing hysterectomy for adenomyosis are in their fourth and fifth decade of life and are multiparous. ${ }^{(16)}$ in our study also majority of patients with adenomyosis were in $4^{\text {th }}$ and $5^{\text {th }}$ decade of life

Coagulopathy was found in only 2 patients in our study $(0.6 \%)$ similar to Quereshi et al $(0.3 \%)$ and Betha Ket al. $(0.8 \%)^{(17)}$

Ovulatory dysfunction was the 2nd most common cause of AUB (13.6\%) in the betha et al study and Arnold et al study had $17.2 \%$ of cases. $^{(18)}$

There are limited studies showing causes of AUB according to PAM COEIN classification system as it is relatively new method .more studies are needed to understand its clinical utility

However in our present study we could understand the major causes of AUB grouped in to structural and non-structural causes. According to a universally accepted definition and hence management was more focussed and tailored to the specific cause instead of just hysterectomy for all causes.

\section{Conclusion}

In our present study we found that structural causes contributed more to the cause of AUB in 30-50 yr age group patients. PALM COEIN classification system helps clinicians to understand various causes of AUB and know the precise pathology so that management can be tailored according to cause and also various treatment strategies can be compared.

\section{References}

1. Fraser IS, Langham S, Uhl-Hochgraeber K. Health-related quality of life and economic burden of abnormal uterine bleeding. Expert Rev Obstet Gynecol. 2009;4:179-89.

2. Shapley M, Jordan K, Croft PR. An epidemiological survey of symptoms of menstrual loss in the community. Br J Gen Pract. 2004;54:359-63.

3. Hoffman BL. Williams Gynecology. 2nd ed. p.a Mc Graw Hill;2012:219-40. )

4. ACOG Committee on Practice Bulletins Gynecology. ACOG Practice Bulletin No 108: Polycystic ovary syndrome. Obstet Gynecol 2009; 114:936-49.

5. Committee on Practice BulletinsGynecology. Practice bulletin no. 128: Diagnosis of abnormal uterine bleeding in reproductive-aged women. Obstet Gynecol 2012; 120(1):197-206.

6. Munro MG, Critchley HO, Broder MS, Fraser IS, FIGO Working Group on Menstrual Disorders System. FIGO classification system (PALM-COEIN) for causes of abnormal uterine bleeding in nongravid women of reproductive age. Int J Gynecol Obstet. 2011;113(1):3-13. 
7. Fraser IS, Critchley HO, Broder M, Munro MG. The FIGO recommendations on terminologies and definitions for normal and abnormal uterine bleeding. Semin Reprod Med. 2011;29(5):383-90.

8. Woolcock JG, Critchley HO, Munro MG, Broder MS, Fraser IS. Review of the confusion in current and historical terminology and definitions for disturbances of menstrual bleeding. Fertil Steril. 2008;90(6):2269-80.

9. Munro MG, Critchley HO, Broder MS, Fraser IS; FIGO Working Group on Menstrual Disorders. FIGO classification system (PALMCOEIN) for causes of abnormal uterine bleeding in nongravid women of reproductive age. Int J Gynaecol Obstet 2011; 113(1):3-13.00

10. Goel and Rathore, PALM-COEIN FIGO Classification for diagnosis of Abnormal Uterine Bleeding: Practical Utility of same at Tertiary Care Centre in North India; Sch. J. App. Med. Sci., 2016; 4(8A):27712773

11. Khrouf M, Terras K; Diagnosis and management of formerly called -dysfunctional uterine bleeding\| according to PALM-COEIN FIGO classification and the newguidelines. JObstet Gynaecol India 2014; 64:388-93.

12. Madhra M, Fraser IS, Munro MG, Critchley HO;Abnormal uterine bleeding: Advantages of formal classification to patients, clinicians and researchers. Acta Obstet Gynecol Scand 2014; 93:619-25

13. Bahamondes L, Ali M; Recent advances in managing and understanding menstrual disorders.F1000 Prime Rep 2015; 7:33.

14. Qureshi FU, Yususf AW; Distribution of causes of abnormal uterine bleeding using the new FIGO classification system. J Pak Med Assoc 2013: 63:974.

15. Gouri S.R.S, Lakshmi P.V, Rani N.G, Kumar N.A;Categorization of the Causes of AUB According to PALM-COEIN
Classification 107 International Journal of Scientific Study, 2016; 4(2).

16. Taran FA, Weaver AL, Coddington CC, Stewart EA. Characteristics indicating adenomyosis coexisting with leiomyomas: a case control study. Hum Reprod. 2010;1177-82.

17. Kalpana Bethaet al . Distribution of causes of abnormal uterine bleeding using new FIGO classification system-PALM COEIN: a rural tertiary hospital based study; International Journal of Reproduction, Contraception, Obstetrics and Gynecology. 2017 Aug;6(8):3523-3527

18. Jonathan AA, Saravanan S. A two year clinicopathological study of non-gravid women with abnormal uterine bleeding in a rural tertiary care centre in Tamilnadu: in concurrence with the Figo recommenddations. J Evol Med Dental Sci. 2015;4(63):10990-1001. 